\title{
Impact of E-Recruitment on Effectiveness of HR Department in Private Sector of Pakistan
}

\author{
Dr. Muhammad Shaukat Malik \\ Director Institute of Banking and Finance (IBF), \\ Bahauddin Zakariya University (BZU), Multan, Pakistan \\ Mr. Muhammad Assad ul Mujtaba (Corresponding author) \\ MS Scholar Institute of Banking and Finance (IBF), \\ Bahauddin Zakariya University (BZU), Multan, Pakistan \\ E-mail: shiningassad@yahoo.com
}

Received: Jan. 30, 2018 Accepted: Mar. 20, 2018 Online published: Mar. 21, 2018

doi:10.5296/ijhrs.v8i2.12869

URL: https://doi.org/10.5296/ijhrs.v8i2.12869

\begin{abstract}
Human Resource (HR) department is one of the most vital departments in any modern organization. Many research studies until date have concluded that HR department plays an important role in the success of any organization. Amongst the various activities, which an HR department expected to conduct, Recruitment holds special importance, as it is concerned with 'bringing people into the organization'. This research paper aims at exploring the impact of latest technological developments (especially the concept of E-Recruitment) in the context of recruitment and how it has facilitated the modern day HR managers. Private Sector is one of the largest and fastest growing sectors of Pakistan and it is generally believed that the private companies operative in Pakistan have well established HR departments that tend to utilize modern technology to assist them with the recruitment activities. Thus, it is only logical to assess the effectiveness of this technology through the example of private sector of Pakistan.

This is a causal research. Causal research is conducted in order to identify the extent and nature of cause-and-effect relationships. Causal research is quantitative in nature as well as preplanned and structured in design like descriptive research. Data collected from the HR professionals, like Head of HR, HR mangers, Deputy \& Assistant HR managers, HR Executive, and HR coordinators of private companies located in Multan, Lahore, Faisalabad,
\end{abstract}


Quetta and Islamabad through questionnaires. Statistical tests like, descriptive analysis, sample adequacy, normality, reliability correlations, regression test were used to generate the results of analysis, because the purpose is to find the impact of E-recruitment on effectiveness of HR Departments.

The result has proved that E-recruitment has significant impact on effectiveness of HR Department in private sector of Pakistan.

Keywords: e-recruitment, human resource management, private sector, Pakistan

\section{Introduction}

In developed countries where economic positions of the country were changing, large companies began delegating the powers of the chief executive to various operational heads such as production, marketing, procurement and most importantly the human resource (HR) department. As Armstrong (2006) states that, the purpose of establishing separate HR departments was to hire talented people against these vacant job positions. With an unprecedented increase in the dynamicity of the business environment, the nature of job is changing every day. Recruitment is one of the most basic functions of HR departments (Chapman \& Webster, 2003). It is a process of sourcing and acquiring the right applicants to an organization. This process comprises of a series of steps through which an organization seeks and attracts a pool of qualified applicants using various feasible recruitment methods (Fisheret. al, 2014).The modern day market is driven by the concept of 'skill development'. There is an increased awareness amongst the companies about recruiting and matching the right resource for the right job and at the right time. However, traditionally the situation was very different, as Sills,M (2014) stated that the recruitment processes within the companies began to get civilized after 1990s. Various organizations began to hire recruitment agencies for performing their recruitment related activities. These agencies were responsible for hiring technical and non-technical staff for these companies. According to Holm, A (2010), as the industries began to offer new jobs on daily basis, the hiring took place on the demand of the market of load of the work. These companies preferred to hire people on daily wages. However, after the industrial revolution in the 1990s, the industries began to seek more technical and trained person for increasing productivity and the quality of the product Sills, M (2014).

The traditional recruitment methods are contacting friends or employee referrals, engaging in executive search, using newspaper ads etc. Holm, A.B (2012). Whenever changes occur in company's policy, technology, location, mergers, acquisitions, employee resignation, this process continues to take place periodically to add, maintain, or re-adjust the workforce. As global competition persists and industries become more skill intensive, the recruitment of talented workers becomes essential and attracting the right applicants at the right time gets complicated than ever Tohidi, H (2014).5 The use of conventional recruitment methods is no longer enough and timely to attract sufficient pool of qualified applicants. Many organizations have turned to adopt sophisticated recruitment strategies or combining various recruitment methods to attract them. (El-Gohary, 2012). 
The rapid growth in technology has brought many changes in each department of organization (Awang et. al, 2013). Many employers are adopting the modern techniques for recruitment \& selection process to find the best suitable candidates (Ensher et. al, 2003). According to Bartram (2000), in the modern world, the recruitment activities are incomplete without the word of 'internet'. In early 2000, the concept of 'job boards' were introduced into the job market. Monster.com was the first recruitment site established in same year (Ensher et. al, 2003).E-recruitment is the latest method of recruitment. Internet can be used as the latest equipment for recruitment and selection. It is a real technological innovation for job seekers and employers. (Parry, E. \& Wilson, H. 2009). The concept of e-recruitment started in HR journals from the mid of 1980. Later on, the development in technology makes HR more effective. The concept of E-HRM was introduced in market in 2000 Sills, M (2014).

The situation of Pakistan is not different also like other developing countries. Here, the large firms also stressed on the E-recruitment after the technological innovation (Ahmed, S., Tahir, H., \&Warsi, S. W. (2015). In Pakistan, many "job boards" are working, like job.com, Rozee.pk, Mustakbil.com and some other social sites like LinkedIn. These jobs boards spread the awareness about the job amongst the job seeker.

Therefore, this is the right time to explore if e-recruitment initiatives in a relatively less developed country like Pakistan are having any impact on balancing the HR supply chain and that if the HR departments within these companies have improved their efficiency or not. This research study is a unique research effort, as very few researchers (until date) have attempted to explore this area. The results of the study can benefit the HR departments of the private sector companies and can facilitate them in designing and implementing e-recruitment technologies within their organizations. This study will determine the effectiveness of such systems and their scope in future.

\section{Literature Review}

Human Resource management consists of three words, i.e. human, resource and management;Human: refer to the skilled workforce of an organization, Resource: refer to limited availability or scarce, while Management: refer to maximize or proper utilization and make best use of limited and a scarce resource (Malik, 2013). The basic function of HRM is dealing to issues related to employees. HRM functioning started from attracting to individuals, selecting the right person and train as per requirement of jobs (Chapman \& Webster, 2003). It is also assessing the ability of the person regarding to the requirement of the job. HR department also measure the performance of employees and granted the right compensation. Parry, E., \& Tyson, S. (2008) .The responsibilities of a human resource manager fall into three areas: defining / designing the work, staffing, employee compensation and benefits (Demirkaya, $\mathrm{H}$ et al., 2011). Recruitment is a main element of human resource management; this function produces human capital for companies. Performance of companies is based upon the better performance of employees (Fisher et al., 2014).

Recruitment relates to reaching out, attracting and ensuring an availability of qualified persons and then finding out right persons Lockyer, C \&Scholaries, D (2004). The recruitment process includes, analyzing the requirements of a job, attracting employees for 
job, screening and selecting applicants, hiring, and integrating the new employee to the organizationFurtmueller, (2012).According to Oliver D.C (2015), recruitment refers to the overall process of attracting, selecting and appointing suitable candidates for jobs. The recruitment sources divided into two categories and these are "Internal Source" recruitment through by transfer or promotion, employee referrals former employee's dependents. "External Source" recruitment through advertisements, educational institute, placement agencies, employment exchange, labor contractors, factory gate and Job portals(M. Badger, et al, 2014).Recruitment process is the backbone of the industry and like other business function; it also needs for continuous improvement (Chauhan, et al., 2013)

The word e- recruitment used first time in the article published in era of 1990s. (Bodea, et al., 2003).In $20^{\text {th }}$ century, E-recruitment became more popular Holm, A. (2014). E-Recruitment consists of two parts. E and Recruitment, E stands for Electronic and recruitment is process of hiring the right persons for right job. E-Recruitment is the latest method of recruitment in which technology (internet) play an important role. Companies own websites or jobs boards are involved to finding, attracting, assessing, interviewing and hiring new persons Oliver, D.C (2015). E- Recruitment is helping the employers can save their time and resources. It is easy to use the recruitment software to shortlist the candidate and the employers can save the data of the applicants (Chapman \& Webster, 2003). E-Recruitment has brought the changes in the life of companies and staff through increasing the productivity and wealth of employer and employees Sharma, V.(2010). Through internet, we use the tools ranging from online newspapers, jobs sites, social sites and online radio stations. Companies have conducted interviews through Skype, Viber or any other online source Marler, J.H \& Fisher, S.L, (2013). E-Recruitment is helping the recruiter to hire the talented staff. Larger pool of applicants is attracting due to E-Recruitment(Parzinger, M. et al., 2013).Cost saving and attracting the large pool of candidate are most important factors of E-Recruitment. Many researchers agreed on, that E-Recruitment is helping the applicant better than the traditional recruitment Sills, M (2014).

E- Recruitment process has reduced the risk regarding the employee background, qualification and its experiences of relevant field (Parry \& Tyson, 2008). The burden of work on HR Mangers, recruitment agencies has reduced because of E-Recruitment techniques Galanki E (2002). Due to E-recruitment stress and cast has reduced. E-recruitment has increased job satisfaction (Walker et al., 2009). E-Recruitment is helping the recruiter in shape of reduced the recruitment cycle Gopalia, A. (2011). It has become very easy to short-list the required technical persons through e-recruitment (Wang et al., 2013). Employers will need to keep profile of employee data and information, and for this purpose database, management is very important. Such databases will store information regarding candidates' contact, qualification and referees. Database will verify the candidates' background, education, driving license, criminal records and previous employment. This will be helpful in consistency and efficiency in recruitment process (El-Gohary, 2012). E-recruitment is facilitating the job seeker better than traditional recruitment. (Khan, et al., 2011) .Therefore, it is the need of time to adapt the Electronic system Ramaabanu\&Saranya (2014). According to Shah et al., (2013) described that; the concept of E- recruitment is not too old in 


\section{Macrothink}

International Journal of Human Resource Studies

ISSN 2162-3058

2018, Vol. 8, No. 2

Pakistan.Technology is the sign of development Teo, T. (2012) New Technologies used for the improvement in productivity. The technological assessment tools are increasing the efficiency and durability of the productAgenyi, B.(2013).

The success of organization not only based on E-Recruitment process, but also proper planning and implementation of the HR system are responsible for organizational success. (Pin et al, 2001).According to the research of Subhani, M. et al., (2012), Candidates was mentioned fake certification and experience in their CVs. Therefore, in developing countries, the first choice of recruiter is to meet the applicants face to face for recruitment process.

Similarly, Kerrin and Katley (2003) pointed out that outdated job postings are another important issue in E-Recruitment system for employer and as well as for applicants.Old job posts and website designing, where jobs portals are not properly visible to the visitors created hurdles for job seekers (Khan,N. et al., 2012).The organizations may find success with online recruitment if they will adopt an appropriate strategy for their use and implementation Nasri,W. \&Charfeddine, L. (2012). The adoption of E-system effectively and its proper implementation are basic requirement of increasing the productivity of organization and performance of employees (You \& Ash, 2014).

Private sector plays an important role for development of Pakistan. Workforce (human Capital) is the base of an organization so many private industries shifted their recruitment system on online. (Khan, N. et al., 2013). The easy access of internet to Pakistani people is providing them with an opportunity to apply against multiple jobs at the same time. According to Kazi, A.K. \&Mannan, M.A. (2013), after the successful experiment of Erecruitment in Modern World, Pakistani employers are also interested and want to implement the system. Nearly 80 to $90 \%$ of the large firms have their own website and they use it for recruitment due to low cost and quick response Imam, H \&Batool S.N (2013). Majority of the private sector in Pakistan like banks, telecom companies, multinational companies,NGOs, Educational Groups and many others have taken the initiatives to recruitment electronically through jobs boards or company's own sites (Amin Mohamed et al,. 2002).

\section{Research Framework}

The thorough analysis of the relevant literature enables the researcher to develop a theoretical framework of a research study. According to several researchers, theoretical framework is the base of the research project. It is logically developed, described and elaborated network of association among the variables deemed relevant to the problem situation and identified through such process as interview, observation, the literature survey. The following model is being proposed as the theoretical framework for this study: 


\section{Macrothink \\ International Journal of Human Resource Studies \\ ISSN 2162-3058 \\ 2018, Vol. 8, No. 2}

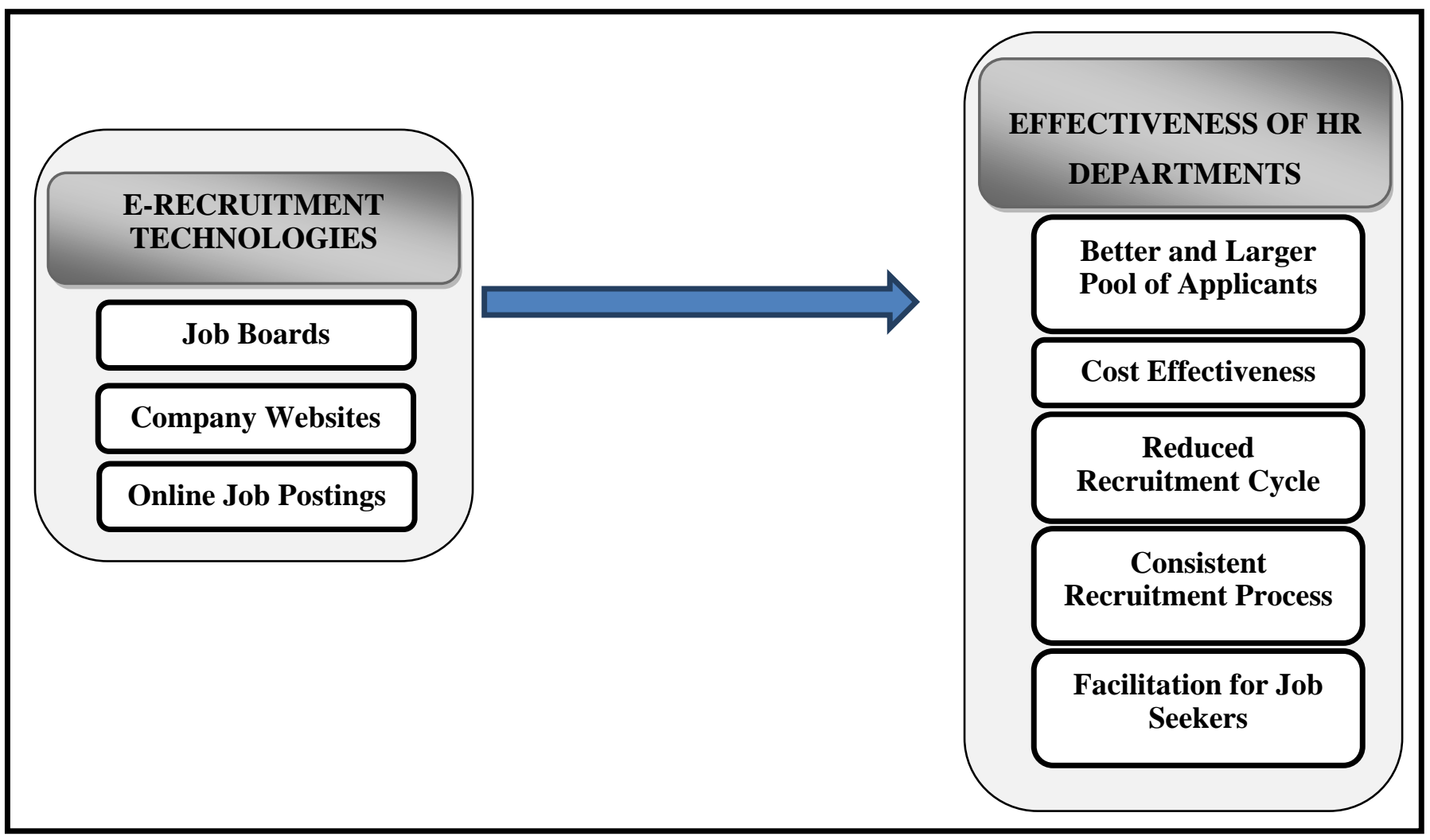

Figure 3.1. Theoretical Framework

\section{Hypotheses Development}

Based upon the conceptual framework developed for this study, the following are the proposed hypotheses statements:

H1: E-recruitment has significant impact on Effectiveness of HR Department in the private sector of Pakistan.

H2: E-Recruitment has a significant relationship with Effectiveness of HR Department in terms of attracting a better and larger pool of applicants in the private sector of Pakistan.

H3: E-Recruitment has a significant relationship with Effectiveness of HR Department in terms of cost effectiveness related to recruitment activities, in the private sector of Pakistan.

H4: E-Recruitment has a significant relationship with Effectiveness of HR Department in terms of reducing the recruitment cycle, in the private sector of Pakistan.

H5: E-Recruitment ha a significant relationship with Effectiveness of HR Department in terms of providing consistency in the recruitment process, in the private sector of Pakistan.

H6: E-Recruitment has a significant relationship with Effectiveness of HR Department in terms of facilitating the potential job seekers, in the private sector of Pakistan.

This research study is a 'Causal Research Study' i.e. it is being conducted to identify the extent and nature of cause-and-effect relationships. Sekran (1990) defines causal research as a 
research conducted to 'investigate' issues. Causal research conducted in order to assess impacts of specific changes on existing norms. Causal research is quantitative in nature as well as preplanned and structured in design. This research study is also 'Quantitative' in nature and involves numbers and many statistical tests. Survey Questionnaire used to gather data from the respondents.

\section{Results and Discussions}

This study is falling in the category of behavioral sciences, so Cronbach's Alpha has been used to ensure the reliability of instrument. An instrument having the Cronbach's Alpha value near to 0.7 considered "accepted" as the reliable instruments. The Cronbach's Alpha value for total number of items included in instrument, which is 0.839 . The value is very close to 0.7 . In hence, it can be said that questionnaire being used for current study is reliable to collect data.

H1: E-recruitment has significant impact on Effectiveness of HR Department in the private sector of Pakistan.

E-Recruitment has a significant relationship with Effectiveness of HR Department.Thus, the hypothesis is accepted. The T.value is 15.279 , which shows that predictor power of independent variable (E-Recruitment) is quite high, while estimated EHRD. The beta coefficient is .723at $\mathrm{P}$ value $<.000$, which implies increase in one unit of independent variable (E-Recruitment) cause 0.723 unit increase in dependent variable (EHRD).Adjusted R2 $=.521$ the value of tolerance is close to 1 which shows that there is no problem of Multicollinearity in the data.

H2: E-Recruitment has a significant relationship with Effectiveness of HR Department in terms of attracting a better and larger pool of applicants in the private sector of Pakistan.

E-Recruitment has a significant relationship with finding the better quality of applicants. Thus, the hypothesis is accepted. The T.value is $\underline{12.019}$, which shows that predictor power of independent variable (E-Recruitment) is quite high, while estimated finding the better quality of applicants. The beta coefficient is .636 at $\mathrm{P}$ value $<.000$, which implies increase in one unit of independent variable (E-Recruitment) cause 0.636 unit increase in dependent variable (finding the better quality of applicants). Due to the E-Recruitment, companies / organizations find the better quality of applicants. Adjusted R2 $=.401$ the value of tolerance is close to 1 which shows that there is no problem ofMulticollinearity in the data.

H3: E-Recruitment has a significant relationship with Effectiveness of HR Department in terms of cost effectiveness related to recruitment activities, in the private sector of Pakistan.

E-Recruitment has a significant relationship with cost effectiveness. Thus the hypothesis is accepted The T.value is $\underline{12.019}$, which shows that predictor power of independent variable (E-Recruitment) is quite high, while estimated cost effectiveness. The beta coefficient is .636 at $\mathrm{P}$ value $<.000$, which implies increase in one unit of independent variable (E-Recruitment) cause 0.636 unit increase in dependent variable (cost effectiveness). Adjusted R2 $=.401$ the value of tolerance is close to 1 which shows that there is no problem of Multicollinearity in the data. The process of E-recruitment is cost effectiveness.

H4: E-Recruitment has a significant relationship with Effectiveness of HR Department in 
terms of reducing the recruitment cycle, in the private sector of Pakistan.

E-Recruitment has a significant relationship with Reduced Recruitment Cycle.Thus the hypothesis is accepted. The T.value is 13.727, which shows that predictor power of independent variable (E-Recruitment) is quite high, while estimated Reduced Recruitment Cycle. The beta coefficient is .685 at $\mathrm{P}$ value $<.000$, which implies increase in one unit of independent variable (E-Recruitment) cause 0.685 unit increase in dependent variable (Reduced Recruitment Cycle). Recruitment Cycle reduced due to the E-Recruitment. Adjusted R2 $=.469$ the value of tolerance is close to 1 which shows that there is no problem of Multicollinearity in the data.

H5: E-Recruitment ha a significant relationship with Effectiveness of HR Department in terms of providing consistency in the recruitment process, in the private sector of Pakistan.

E-Recruitment has a significant relationship with consistency in recruitment process. Thus, the hypothesis is accepted. The t-value is 11.029 , which shows that predictor power of independent variable (E-Recruitment) is quite high, while estimating that recruitment process becomes consistent. The beta coefficient is .531 at $\mathrm{P}$ value $<.000$, which implies increase in one unit of independent variable (E-Recruitment) cause 0.531 unit increase in dependent variable. Adjusted R2 = .304 and the value of tolerance is close to 1which shows that there is no problem of Multicollinearity in the data.

H6: E-Recruitment has a significant relationship with Effectiveness of HR Department in terms of facilitating the potential job seekers, in the private sector of Pakistan.

E-Recruitment has a significant relationship with facilitation of job seekers.Thus the hypothesis is accepted. The t-value is $\underline{13.379}$, which shows that predictor power of independent variable (E-Recruitment) is quite high, while estimating facilitation for job seekers. The beta coefficient is .676 at $\mathrm{P}$ value $<.000$, which implies increase in one unit of independent variable (E-Recruitment) cause 0.676 unit increase in dependent variable (facilitation of job seekers). The job seekers feel more confident and convenient applying online for a job, as it is easier for them to submit their resumes and get a timely response from their potential employers. Adjusted R2 $=.454$ the value of tolerance is close to 1 which shows that there is no problem of Multicollinearity in the data.

The results of the study clearly indicate that the organizational culture plays a vital role in adoption of e-recruitment technologies. As Dhamija (2012) suggested that adopting E-Recruitment, technology requires a coordinated effort between the top-level management and the employees.

The privates companies related to service providing are making an effort in bringing some change in the HR policies and practices in Pakistan. They are happily using latest technological solutions for their HR activities. This trend in Pakistani companies is consistent with the observations of Budhwar and Sparrow (1997), Abel, S. (2011), who stated that service sector industries have adopted 'internet' as the primary communication tool. They prefer using this medium of communication with internal and external contacts. Similarly Ngai et al. (2008) also stated that service sector industries are investing more on technological solutions related to HR. They are developing their own databases, which have the capacity to store large size data. Through this initiative, they are able to collect 
applications from all the over the world and hence the recruit the best possible talent. According to Martins, C. et al., (2014), service sector industries are particularly interested in the 'auto-screening' functionalities provide by the e-recruitment software.

The result shows that E-recruitment has significant relationship with attracting better quality of applicants $(r=0.664)$. The impact of E-recruitment on better quality of applicants is accepted. This is in accordance with the study of Katou and Budhwar (2006) and Galanki (2002).

Similarly, a large set of job seekers are being facilitated using the e-recruitment technology ( $\mathrm{r}$ $=0.663)$. The availability of internet across the country and strength of web users is increasing day by day. Nearly 10 billion people have access to internet in Pakistan. Web surfing is also easier and cheaper due to the growth of broadband. Resultantly the E-recruitment is becoming easier than any other method of recruitment, therefore large number of applicants used online recruitment. This trend is consistent with the studies of Awan, Ghouri and Khan (2013) ,Carrillat, F. et al., (2014) suggested that e-recruitment is the only method through which an applicant can apply for a job 24 hours and 7 days a week, without any restriction. The potential applicants in Pakistan are beginning to understand such benefits of online recruitment.

The result shows that E-recruitment has significant relationship cost effectiveness $(r=0.613$ for using own website and $r=0.471$ for using external job boards). E-recruitment is helping to save costs, like administrative and operational costs involved in the traditional recruitment processes. Chuhan, R.S et al., (2013) and Carrillat, F. et al., (2014) reported the same finding. E-recruitment has very significant relationship reduced recruitment cycle $(r=0.748)$. Due to E-Recruitment, the recruitment cycle is reduced. The impact of E-recruitment on reduced recruitment cycle is accepted. It may possible, that all recruitment process can be completed in 24 hours. The processes run quickly as compared to the traditional recruitment. Feldman, D.C. \&Klaas, B.S. (2002) and Faliagka, E. et al., (2012), reported the same finding.

The result shows that E-recruitment has significant relationship with consistent in recruitment process. The impact of E-recruitment on consistency in recruitment process is accepted. The results of this hypothesis are consistent with the studies of Pin, Laorden and Diez (2001) and Ventura, M. G. G., \&Bringula, R. P. (2013). E-recruitment has significant relationship with facilitation for job seeker. The impact of E-recruitment on facilitation for job seeker is accepted. The same finding has reported by (Awang, M., Ghouri, a. M., \& Khan, N. R. (2013) \&Ahmed, S., Tahir, H., \&Warsi, S. W. (2015).

\section{Recommendations for HR Departments}

Based upon the results generated in this study and the fact that technology adoption is not acting as a moderator between e-recruitment and HRSCM, the following recommendations can be made to the HR departments operating in the private sector companies of Pakistan:

i. There is a need to conduct a 'coordinated' effort in designing, implementing and then using technological solutions within the Pakistani companies. The general impression is that a technological solution e.g. e-recruitment solution is 'imposed' on the employees by the top-level management. The middle level or first level management 
are unable to understand the benefits of technology and therefore treat this system as a 'burden'. Using a system unwillingly surely reduces its effectiveness.

ii. There is no need to implement comprehensive and complete technological solutions at once. The systems should be implemented component by component. The target should be to familiarize the employees with new systems. Spending large budgets on systems, with which the potential users are uncomfortable, is one of the common reasons for low technology adoption in Pakistani organizations.

iii. The websites or web portals through which some of the companies are conducting their recruitment efforts should be attractive and user friendly. These web portals should be developed from the applicant perspective i.e. to provide more facilities and ease to the applicants.

iv. The company HR databases should be regularly updated.

v. Training must be provided to all HR persons for increasing their capabilities to deliver the proper result and actual benefits of E-recruitment.

vi. Develop a monitoring system to evaluate and assess the post-hire performance levels of employees recruited to assess the overall effectiveness of e-recruitment.

\section{Limitations}

Although every effort has been made to conduct a comprehensive research study, yet due to time and budget constraints, there are certain limitations of the study:

$i$. The dataset of the study comprises of responses from 215 people, spread across six cities of Pakistan. The scope of the research can be enhanced by adding more respondents and more organizations operating in Pakistan.

\section{Future Research Areas}

Several areas can stem-out from the results generated from this study, such as:

- The potential future research areas in this domain can be an analysis of the public sector organizations in Pakistan.

- More importantly, a comprehensive study that discusses the possibility of implementing complete HR Management Information Systems in Pakistani companies can also be conducted.

- Likewise, the impact of E-Recruitment on Effectiveness of HR Department could be comparedbetween Private and Public sector or service industry and manufacturing industry or large and small industries.

- Further research on employer behavior towards technology adoption is also a very important area of research.

- This study can also be replicated with a bigger sample size. 


\section{References}

Abel, S. (2011). The role of social networking sites in recruitment: Results of a quantitative study among German companies. Dissertation: University of Twente, Netherlands.

Agenyi, B. (2013). Mobile Banking and Entrepreneurship in Developing Countries: A case study of Nigeria.

Ahmed, S., Tahir, H., \& Warsi, S. W. (2015). E-Recruitment Transforming the Dimensions of Online Job Seeking: A case of Pakistan. International Journal of Human Resource Studies, 5(1), Pages-96. https://doi.org/10.5296/ijhrs.v5i1.6161

Amin, M. A., Orife, J. N., \& Wibowo, K. (2002). The legality of key word search as a personnel selection tool. Employee Relations, 24(5), 516-522. https://doi.org/10.1108/01425450210443285

Armstrong, M. (2006). Human Resource Management. In M. Armstrong, A Handbook of Human Resource Management Practice (p. 3). London: Kogan Page Limited.

Awang, M., Ghouri, A. M., \& Khan, N. R. (2013). Impact of e-recruitment and job-seekers perception on intention to pursue the jobs. Management and Marketing Criova, (1), 47-57.

Badger, J. M., Kaminsky, S. E., \& Behrend, T. S. (2014). Media richness and information acquisition in internet recruitment. Journal of Managerial Psychology, 29(7), 866-883. https://doi.org/10.1108/JMP-05-2012-0155

Bartram, D., \& Hambleton, R. K. (2006). Computer-based testing and the Internet. Issues and advantes.England: John Wiley and Sons.

Bodea, C., Bodea, V., \& Zsolt, M. (2003). Human Resource Management in the Internet Age: e-Recruitment and e-Selection Methods. Economy Informatics, 3(3), 5-7.

Budhwar, P., \& Sparrow, P. (1997). Evaluating levels of strategic integration anddevolvement of human resource management in India", International Journal of HumanResource Management, 8, 476-494. https://doi.org/10.1080/095851997341568

Carrillat, F., d'Astous, A., \& Morissette, G. E. (2014). Leveraging social media to enhance recruitment effectiveness: A Facebook experiment. Internet Research, 24(4), 474-495. https://doi.org/10.1108/IntR-07-2013-0142

Carrillat, F., d'Astous, A., \&Morissette, G. E. (2014). Leveraging social media to enhance recruitment effectiveness: a Facebook experiment.Internet Research, 24(4), 474-495. https://doi.org/10.1108/IntR-07-2013-0142

Chapman, D., \& Webster, J. (2003). The Use of Technologies in Recruiting, Screening, and Selection Processes for Candidates", International Journal of Selection and Assessment, 11(2/3), 113-120. https://doi.org/10.1111/1468-2389.00234

Chauhan, R. S., Buckley, M., \& Harvey, M. (2013). Facebook and personnel selection: what's the big deal? Organizational Dynamics, 42(3), 126-134. https://doi.org/10.1016/j.orgdyn.2013.03.006

Demirkaya, H., Özcüre, G., \& Eryiğit, N. (2011). An application on the impacts of human resource management in technology management of the companies. Procedia-Social and Behavioral Sciences, 24, 474-486. https://doi.org/10.1016/j.sbspro.2011.09.045 
Dhamija, P. (2012). E-recruitment: a Roadmap towards e-Human Resource Management.Researchers World - International Refereed Journal of Arts Science \& Commerce Research (RW-JASCR), 3(3(2)), 33-39.

El-Gohary, H. (2012). Factors affecting E-Marketing adoption and implementation in tourism firms: An empirical investigation of Egyptian small tourism organizations. Tourism Management, 33(5), 1256-1269. https://doi.org/10.1016/j.tourman.2011.10.013

Ensher, E. A., Nielson, T. R., \& Grant, V. E. (2003). Tales from the hiring line: effects of the internet and technology on HR processes. Organizational Dynamics, 31(3), 224-244. https://doi.org/10.1016/S0090-2616(02)00111-0

Faliagka, E., Tsakalidis, A., \&Tzimas, G. (2012). An integrated e-recruitment system for automated personality mining and applicant ranking. Internet research, 22(5), 551-568. https://doi.org/10.1108/10662241211271545

Feldman, D. C., \& Klaas, B. S. (2002). Internet Job Hunting: A Field Study of Applicant Experiences with On-Line Recruiting”, Human Resource Management, 41(2), 175-192. https://doi.org/10.1002/hrm.10030

Fisher, R., McPhail, R., You, E., \& Ash, M. (2014). Using social media to recruit global supply chain managers. International Journal of Physical Distribution \& Logistics Management, 44(8/9), 635-645. https://doi.org/10.1108/IJPDLM-07-2013-0179

Furtmueller, E. (2012). Using technology for global recruitment: why HR/OB scholars need US knowledge? Dissertation: University of Twente, Netherlands

Galanaki, E. (2002). The Decision to recruit Online: A Descriptive Study, Career International Development, 7(4), 243-251. https://doi.org/10.1108/13620430210431325

Gopalia, A. (2011). Effectiveness of online recruitment and selection process: a case of Tesco.

Holm, A. (2010, May). The effect of e-recruitment on the recruitment process: Evidence from case studies of three Danish MNCs. In Proceedings of the 3rd European academic workshop on electronic human resource management (pp. 91-111).

Holm, A. (2014). Institutional context and e-recruitment practices of Danish organizations. Employee Relations, 36(4), 432-455. https://doi.org/10.1108/ER-07-2013-0088

Holm, A. B. (2012). E-recruitment: Towards an Ubiquitous Recruitment Process and Candidate Relationship Management. ZeitschriftfürPersonalforschung - German Journal of Research in Human Resource Management, 26(3), 241-259. https://doi.org/10.1177/239700221202600303

Holm, B. A. (2014). Institutional context and e-recruitment practices of Danish organizations. Employee Relations, 36(4), 432-455. https://doi.org/10.1108/ER-07-2013-0088

Imam, H., \& Batool, S. N. (2013). Organizational Perception Regarding Specific Information about Job and Organization: An Approach to E-Recruitment. International SAMANM Journal of Business and Social Sciences, 1(1), 26-33.

Katou, A. A., \& Budhwar, P. S. (2006). Human Resource Management Systems andOrganizational Performance: A Test of a Mediating Model in the Greek Manufacturing. Context", The International Journal of Human Resource Management, 17(7), 1223-1253. https://doi.org/10.1080/09585190600756525 


\section{$\triangle 1$ Macrothink}

International Journal of Human Resource Studies ISSN 2162-3058 2018, Vol. 8, No. 2

Kazi, A. K., \&Mannan, M. A. (2013). Factors affecting adoption of mobile banking in Pakistan: Empirical Evidence. International Journal of Research in Business and Social Science, 2(3), 54.

Kerrin, M., \& Kettley, K. (2003), E-recruitment: Is it Delivering? Institute of Employment Studies.Report 402.

Khan, N. R., Awang, M., \&Ghouri, A. M. (2013). Impact of E-Recruitment and Job-Seekers Perception on Intention to Pursue the Jobs. Khan, NR, Awang, M., \&Ghouri, AM(2013). Impact of E-Recruitment and Job-Seekers Perception on Intention to Pursue the Jobs. Management \& Marketing, 11(1), 47-57.

Khan, N. R., Taha, S. M., \&Ghouri, A. M. (2011). Bridging the gap through e-recruitment: Evidences from private employment sector in Karachi. Indian Journal of Commerce \& Management Studies, 2(6), 40.

Lockyer, C., Scholarios, D. (2004). Selecting hotel staff: why best practice does notalways work", International Journal of Contemporary Hospitality Management, 16(2), 125-136. https://doi.org/10.1108/09596110410520016

Malik, Z. (2013). The Role of E-recruitment Towards Attraction of Workforce: A Case of Telecom Sector Organization. Abasyn University Journal of Social Sciences, 6(1).

Malinowski, J., Keim, T., \&Weitzel, T. (2005, December 31). Analyzing the Impact of IS Support on Recruitment Processes: An E-Recruitment Phase Model. Pacific Asia Conference on Information System (PACIS) 2005 Proceedings.

Marler, J. H., \& Fisher, S. L. (2013). An evidence-based review of e-HRM and strategic human resource management. Human Resource Management Review, 23(1), 18-36. https://doi.org/10.1016/j.hrmr.2012.06.002

Martins, C., Oliveira, T., \&Popovič, A. (2014). Understanding the Internet banking adoption: A unified theory of acceptance and use of technology and perceived risk application. International Journal of Information Management, 34(1), 1-13. https://doi.org/10.1016/j.ijinfomgt.2013.06.002

Nasri, W., \& Charfeddine, L. (2012). Factors affecting the adoption of Internet banking in Tunisia: An integration theory of acceptance model and theory of planned behavior. The Journal of High Technology Management Research, 23(1), 1-14. https://doi.org/10.1016/j.hitech.2012.03.001

Ngai, E. W. T., Law, C. C. H., Chan, S. C. H., \& Wat, F. K. T. (1971). Importance ofthe internet to human resource practitioners in Hong Kong, Personnel Review, 37(1).

Oldham, G. R., \& Da Silva, N. (2015). The impact of digital technology on the generation and implementation of creative ideas in the workplace. Computers in Human Behavior, 42, 5-11. https://doi.org/10.1016/j.chb.2013.10.041

Oliver, D. C. (2015, August). Recruitment Sources and Natal Dispersal of Catfishes in the Middle Mississippi and Lower Ohio River Inferred from Otolith Chemistry. In 145th Annual Meeting of the American Fisheries Society.Afs.

Parry, E., \& Tyson, S. (2008). An analysis of the use and success of online recruitment mehtods in the UK. (C. S. Management, Éd.) Human Resource Management , 18(3), 257-274. 
Parry, E., \& Wilson, H. (2009). Factors Influencing the Adoption of OnlineRecruitment, Personnel Review, 38(6), 655-673. https://doi.org/10.1108/00483480910992265

Parzinger, M. J., Ward, S. G., \& Langford, M. (2013). Web Recruitment: Impact of Aesthetics and Playfulness on User's Initial Affective Reactions as it Relates to Applicant Attraction. In Proceedings of the Conference for Information Systems Applied Research ISSN (Vol. 2167, p. 1508).

Pawan, S. B. (2000). Evaluating levels of strategic integration and devolvement of human resource management in the UK, Personnel Review, 29(2), 141 - 157. https://doi.org/10.1108/00483480010295952

Pin, R. J., Laorden, M., \& Sáenz, D. I. (2001). Internet Recruiting Power: Opportunities and Effectiveness, IESE Research Papers D/439, [online] (cited 25 May2006) Available from http://www.iese.edu/research/pdfs/DI-0439-E.pdf

Ramaabaanu, R., \&Saranya, M. (2014). Importance and Problems of E-Recruitment. International Journal of Research, 1(9), 445-450.

Shah, G. U. D., Bhatti, M. N., Iftikhar, M., Qureshi, M. I., \& Zaman, K. (2013). Implementation of technology acceptance model in e-learning environment in rural and urban areas of Pakistan. World Applied Sciences Journal, 27(11), 1495-1507.

Sharma, V. (2010). Impact of e-recruitment on Human resource Supply chain Management: An Empirical Investigation of service industry in Indian Context (Doctoral dissertation, Jaypee Institute of Information Technology, Noida).

Sills, M. (2014). E-recruitment: A comparison with traditional recruitment and the influences of social media: A qualitative and quantitative review.

Subhani, M. I., Joseph, S., Osman, A., \& Hasan, S. A. (2012). Contribution of Linkedin on Recruitment and Selection. South Asian Journal of Management Sciences (SAJMS), Iqra University, 6(2), 23-34.

Teo, T. (2012). Examining the intention to use technology among pre-service teachers: an integration of the Technology Acceptance Model and Theory of Planned Behavior. Interactive Learning Environments, 20(1), 3-18. https://doi.org/10.1080/10494821003714632

Tohidi, H. (2011). Human Resources Management main role in Information Technology project management. Procedia Computer Science, 3, 925-929. https://doi.org/10.1016/j.procs.2010.12.151

Veger, M. (2006). How does Internet recruitment have effect on recruitment performance? Fourth Twente Student Conference on IT, 30.

Ventura, M. G. G., \&Bringula, R. P. (2013). Effectiveness of Online Job Recruitment System: Evidence from the University of the East. IJCSI International Journal of Computer Science Issues, 10(4), 152-159.

Wang, Y., Sun, S., Drake, J. R., \& Hall, D. (2013). Job Applicants' Information Privacy-Protective Response: Exploring the Roles of Technology Readiness and Trust.

Yoon, K. T. D. (2009). A study of e-recruitment technology adoption in Malaysia. Industrial Management \& Data Systems, 109(2), 281-300. https://doi.org/10.1108/02635570910930145 


\section{Copyright Disclaimer}

Copyright for this article is retained by the author(s), with first publication rights granted to the journal.

This is an open-access article distributed under the terms and conditions of the Creative Commons Attribution license (http://creativecommons.org/licenses/by/4.0/). 